\title{
TINDAK BAHASA TERAPIS DALAM INTERVENSI KLINIS PADA ANAK AUTIS
}

\author{
Luluk Sri Agus Prasetyoningsih \\ FKIP Universitas Isalam Malang \\ e-mail: luluksap@yahoo.com
}

\begin{abstract}
Abstrak
Penelitian ini bertujuan mendeskripsikan jenis, fungsi, dan strategi tindak bahasa terapis dalam intervensi klinis kepada anak autis. Penelitian ini menggunakan pendekatan kualitatif dengan ancangan pragmatik klinis. Hasil penelitian sebagai berikut. Pertama, terapis intervensi klinis anak autis menggunakan jenis tindak ilokusi berupa tindak direktif, asertif, dan ekspresif. Secara umum terapis intervensi klinis anak autis menggunakan tindak ilokusi dengan pola tuturan sederhana. Kedua, tindak verbal terapis memiliki fungsi memerintah, mengajak, meminta, menolak, menanyakan, menyetujui, menyatakan, menjelaskan, memuji, bersyukur, dan berterima kasih. Ketiga, strategi tindak bahasa terapis berupa strategi tuturan langsung dengan cara pemanggilan, pemberian petunjuk, dan penggunaan visual atau model.
\end{abstract}

Kata kunci: tindak bahasa, terapis, intervensi klinis, anak autis

\section{THERAPEUTIC LANGUAGE ACTS IN CLINICAL INTERVENTIONS ON AUTISTIC CHILDREN}

\begin{abstract}
This study aims to describe types, functions, and strategies of therapeutic language acts in clinical interventions on autistic children. It employed the qualitative approach using the clinical pragmatic design. The findings are as follows. First, clinical therapeutic interventions on autistic children use illocutionary acts in the forms of directive, assertive, and expressive acts. In general, they use simple utterance patterns. Second, therapeutic verbal acts have functions to command, invite, require, refuse, ask, agree, state, explain, compliment, thank God, and thank. Third, strategies of therapeutic language acts are in the form of direct utterance strategies by means of calling, giving directions, and using visual objects or models.
\end{abstract}

Keywords: language acts, therapeutic, clinical interventions, autistic children

\section{PENDAHULUAN}

Autis merupakan gangguan perkembangan komunikasi, interaksi sosial, dan perilaku. Gangguan perkembangan tersebut dapat dideteksi sebelum anak berusia tiga tahun. Gejala-gejala pada anak autis dapat diketahui setelah anak dilahirkan dan dalam perkembangannya mengalami abnormal. Orang tua dapat segera mengetahui apakah anak mengalami gangguan autis dengan cara membandingkan pada anak seusia dalam perkembangan normal.

Terdapat tiga ciri umum autis yang disebut dengan tiga kelainan (triad of impairment), yaitu kesulitan bersosialisasi, berimajinasi atau perilaku, serta berkomunikasi verbal dan nonverbal. Misalnya kesulitan memahami gerakan tubuh, ekspresi muka, dan kesulitan me- 
mahami kapan seharusnya memulai atau mengakhiri percakapan. Pada umumnya anak autis gangguan komunikasi mengalami hambatan dalam penggunaan bahasa dan secara khusus ditandai dengan defisit komunikasi. Adanya kelainan khusus bahasa (specific language impairment) pada anak autis memunculkan penghalang bagi komunikasi yang efektif.

Menurut SES (2002:35) berdasarkan hasil penelitian secara internasional menunjukkan bahwa prevalensi anak autis semakin meningkat dengan perbandingan 10:1000. Artinya, setiap seribu anak normal terdapat sepuluh anak dengan gangguan autis. Demikian juga di Indonesia, menurut ahli neurologi jumlah penderita autis cukup besar. Prevalensi gangguan spektrum autis cukup tinggi dengan perbandingan 8:1000 (Nugroho 2011:1). Bahkan, diprediksi jumlah anak autis pada tahun 2010 mencapai $60 \%$ dari keseluruhan populasi anak di seluruh dunia (Wijayakusuma, 2009:vi).

Anak autis yang mengalami gangguan perkembangan bahasa mengalami kesulitan berkomunikasi. Masalah ketidakmampuan berbahasa yang berhubungan dengan defisit kompetensi pragmatik diperlukan asesmen dan terapi. Autis sebagai bentuk gangguan pertumbuhan mempengaruhi kemampuan anak berinteraksi atau berkomunikasi perlu ditangani sejak dini. Berdasarkan data empiris, gangguan komunikasi pada anak autis dapat diatasi, antara lain melalui intervensi klinis atau disebut terapi (Priyatna, 2010:39 dan Delphie, 2009:23-24).

Para ahli terapi dari Royal College of Speech and Language menjelaskan bahwa gangguan-gangguan perkembangan bahasa dan pragmatik merupakan kendala yang dapat menghalangi komunikasi efektif. Pada anak-anak dan orang dewasa yang mengalami gangguan komunikasi biasanya perkembangan bahasa dan pragmatik diperoleh secara tidak normal. Kasus gangguan perkembangan bahasa dan pragmatik sering terjadi pada anak-anak autis. Gangguan bahasa semacam ini disebut language disorder (Cummings,1999:360 dan Owens, 1991:3).

Anak autis perlu mendapatkan terapi dalam rangka membangun kondisi yang lebih baik. Terapi untuk anak autis yang mengalami gangguan komunikasi mempunyai tujuan mengurangi masalah komunikasi, meningkatkan kemampuan dan perkembangan belajar dalam hal penguasaan bahasa, serta membantu agar mampu bersosialisasi dan beradaptasi dengan lingkungan.

Pada saat melakukan intervensi seorang terapis bisa memancing dengan baik tindak komunikasi dari klien (anak autis) untuk pemeriksaan klinis (Cummings, 2010:29). Ada dua kompetensi tindak bahasa yang dipersyaratkan agar terapis dapat mencapai sasaran yang sesuai dengan kegiatan klinis, yaitu kompetensi linguistik dan pragmatik.

Anak autis yang memiliki defisit pragmatik tidak mampu menyusun tindak komunikasi atau tindak bahasa sesuai dengan keadaan pengetahuan mitra tuturnya. Dalam kegiatan terapi biasanya terapis berusaha memberikan stimulus agar klien dapat memberikan respon dengan baik. Kemampuan untuk menghasilkan tindak bahasa terapi tersebut merupakan aspek penting kompetensi pragmatik yang diselidiki pragmatik klinis.

Berdasarkan fakta sosial, terapis atau ahli klinis berusaha keras agar anak autis dapat memahami tindak komunikasi. Dalam intervensi klinis, terapis berusaha agar anak autis mampu memulai dan melanjutkan pembicaraan dengan orang lain meskipun dalam percakapan sederhana. Ketidakmampuan merespon merupakan salah satu ciri autis spektrum komunikasi. Oleh karena itu, intervensi dari terapis berupa tindak bahasa klinis perlu dilakukan agar defisit komunikasi yang dialami oleh anak autis dapat diatasi. Dalam peristiwa komunikasi klinis, terapis 
menggunakan tindak bahasa atau disebut tindak verbal.

Menurut Searle (1969:23) dalam praktik penggunaan bahasa terdapat tiga macam tindak verbal (tindak tutur), yaitu tindak lokusi, ilokusi, dan perlokusi. Dalam peristiwa tutur dengan aneka latar belakang sosial yang mewadahinya tindak ilokusi merupakan jenis tindak bertutur yang sering digunakan. Dalam fakta sosial yang berlatar klinis, jenis tindak bertutur tersebut digunakan terapis dalam intervensi klinis. Dalam komunikasi klinis terapis menggunakan tindak berbahasa sesuai dengan keadaan pengetahuan mitra tuturnya. Fakta di lapangan menunjukkan bahwa anak autis gangguan komunikasi mengalami kesulitan memahami tuturan. Dalam intervensi klinis, terapis memilih tindak bahasa klinis sesuai dengan karakteristik indidual anak autis, karena masing-masing anak autis memiliki keunikan.

Masalah penggunaan bahasa terapi untuk anak autis menarik untuk diteliti. Penelitian ini khusus mengkaji tindak verbal terapis dalam intervensi klinis anak autis gangguan komunikasi. Secara umum masalah penelitian ini adalah bagaimanakah tindak bahasa terapis dalam intervensi klinis (pembelajaran) anak autis? Rumusan masalah khusus penelitian sebagai berikut. Pertama, bagaimanakah jenis tindak verbal terapis dalam intervensi klinis anak autis. Jenis tindak bahasa ini dideskripsikan berdasarkan jenis realisasi tuturan terapis saat melakukan intervensi klinis anak autis gangguan komunikasi. Kedua, bagaimanakah fungsi tindak verbal terapis dalam intervensi klinis anak autis. Fungsi tindak bahasa ini dideskripsikan berdasarkan maksud penggunaan tuturan terapis dikaitkan dengan konteks klinis. Ketiga, bagaimanakah strategi tindak verbal terapis dalam intervensi kilinis anak autis. Strategi tindak verbal terapis dideskripsikan berdasarkan cara penuturan terapis dalam intervensi klinis anak autis.

\section{METODE}

Penelitian ini menggunakan pendekatan kualitatif dengan tujuan mendeskripsikan tindak bahasa terapis dalam intervensi klinis anak autis gangguan komunikasi. Data penelitian bersifat otentik dan alamiah, karena data diperoleh dari tuturan terapis dalam latar alami. Penelitian ini menggunakan ancangan pragmatik klinis. Menurut Cummings, (2010) ancangan pragmatik klinis merupakan analisis terhadap gangguan penggunaan bahasa berdasarkan konteks klinis. Konteks klinis yang dimaksud merupakan peristiwa klinis saat terapis melakukan kegiatan intervensi anak autis. Ancangan penelitian ini dalam latar alamiah dan otentik pada individu atau kelompok anak autis gangguan komunikasi.

Sumber data penelitian adalah tuturan klinis terapis saat melakukan intervensi anak autis gangguan komunikasi disertai gangguan kompleks. Instrumen utama penelitian adalah peneliti dan pengambilan data dilakukan dengan teknik rekaman video gambar pada peristiwa komunikasi klinis.

Data penelitian berupa data verbal (tuturan) terapis dan dianalisis dengan menggunakan langkah-langkah sebagai berikut. Data yang berupa hasil rekaman video (audio visual) ditranskripsikan dalam bentuk data tertulis. Data yang telah ditranskripsikan kemudian direduksi. Kegiatan ini dilakukan dengan menyeleksi data yang relevan dengan permasalahan penelitian. Kodifikasi data merupakan pemberian kode data hasil reduksi. Data yang sudah dikodifikasi disajikan dalam bentuk matriks atau tabel carta data terpilih. Interpretasi dan eksplanasi dilakukan dengan cara mendeskripsikan dan menjelaskan temuan penelitian berupa jenis, fungsi, dan strategi tindak bahasa terapis. Penyimpulan merupakan hasil akhir penelitian berdasarkan tujuan penelitian. 


\section{HASIL DAN PEMBAHASAN Jenis Tindak Verbal Terapi}

Terkait dengan permasalahan penelitian ini ada tiga jenis tuturan yang dijadikan fokus penelitian tindak verbal terapis. Jenis tidak verbal terapis merupakan wujud realisasi tuturan terapis saat intervensi klinis anak autis. Berdasarkan analisis data penelitian ditemukan beberapa hal.

Pertama, hasil penelitian ini menunjukkan bahwa dalam intervensi klinis anak autis, terapis menggunakan tindak ilokusi dengan pola sederhana. Terapis menggunakan jenis tuturan ilokusi karena tuturan terapis memiliki maksud dan fungsi tertentu yang mengandung tindakan. Dalam penelitian ini tindak bertutur ilokusi dirinci berdasarkan jenis realisasi tuturan. Hasil penelitian menunjukkan bahwa dalam tindak ilokusi terapis ditemukan adanya penggunaan tiga jenis tindak tutur.

Tindak direktif merupakan tindak tutur yang dalam menyampaikan tuturan mengharapkan anak autis melakukan tindakan. Dengan tindak direktif ini terapis berusaha agar anak autis melakukan sesuatu atau tindakan tertentu saat intervensi klinis. Dalam intervensi klinis anak autis, penggunaan tindak direktif terapis ditandai adanya tuturan yang mengandung: perintah, ajakan, penolakan, permintaan, pertanyaan, dan persetujuan. Tindak direktif terapis dideskripsikan sebagai berikut: Bentuk perintah ditandai dengan penggunaan intonasi perintah. Bentuk ajakan atau dorongan ditandai dengan penggunaan tuturan "ayo". Bentuk larangan ditandai dengan penggunaan tuturan "tidak". Hampir semua bentuk larangan atau penolakan menggunakan tuturan "tidak". Bentuk permintaan ditandai dengan penggunaan tuturan "minta". Bentuk pertanyaan dengan jawaban singkat dan tertutup. Pertanyaan dengan jawaban singkat, misalnya "apa, siapa, mana, dimana, dan berapa" Bentuk persetujuan ditandai dengan tuturan "Ok".
Tindak asertif merupakan tindak tutur dalam menyampaikan suatu hal terapis menggunakan proposisi tertentu sehingga mewakili ekspresi kebenaran dari sesuatu yang disampaikannya. Wujud tuturan ini mengikat terapis akan kebenaran apa yang diujarkannya. Ada dua indikator wujud tindak asertif, yaitu bentuk pernyataan dan penjelasan. (a) Bentuk pernyataan ditandai adanya tuturan yang berisi pernyataan sikap terapis terhadap tindakan anak autis. (b) Bentuk penjelasan ini yang berupa deskripsi benda atau penjelasan tentang sesuatu hal.

Tindak ekspresif merupakan tindak tutur yang menyatakan suasana hati atau perasaan terapis. Ada dua indikator tindak ekspresif, yaitu bentuk pujian dan bersyukur atau berterima kasih. Bentuk pujian ditandai adanya penggunanan tuturan "pintar" dan "hebat". Bentuk berterima kasih ditandai dengan penggunaan ucapan "terima kasih", dan bentuk bersyukur ditandai dengan ucapan "alhamdulillah".

Temuan penelitian ini menunjukkan bahwa tindak deklaratif dan tindak komisif tidak digunakan oleh terapis saat intervensi klinis anak autis. Hal ini sesuai dengan karakteristik anak autis sebagai mitra tutur yang memiliki keterbatasan dalam bertutur. Anak autis gangguan komunikasi tidak mampu memahami tuturan yang berisi pengharapan, janji, pengiasan, atau metafora. Hasil penelitian ini mendukung temuan peneliti sebelumnya sebagaimana dikemukakan Cumming (2010: 43) bahwa anak-anak dan orang dewasa yang mengidap sindrom Asperger-varian autisme mengalami kesulitan dalam memahami bahasa nonharfiah, seperti ironi dan metafora. Demikian juga anak-anak yang mengalami kerusakan otak kanan dan otak kiri ternyata juga lemah dalam memahami peribahasa dan idiom.

Kedua, dalam intervensi klinis anak autis, terapis tidak menggunakan tindak lokusi dan perlokusi. Terapis tidak meng- 
gunakan tindak lokusi karena kegiatan intervesi klinis anak autis berhubungan dengan tindakan, sedangkan tindak lokusi merupakan tindak tutur dengan kata, frasa, dan kalimat yang tidak mengandung muatan tindakan. Selama intervensi klinis, terapis tidak menggunakan tindak perlokusi yang bermaksud mempengaruhi anak autis. Hal ini sesuai dengan pendapat Searle (1969:23) dalam praktik penggunaan bahasa (language use) terdapat tiga macam tindak tutur meliputi tindak lokusi, ilokusi, dan perlokusi. Tindak ilokusi paling sering digunakan dalam peristiwa tutur dengan aneka latar belakang situasi sosial yang mewadahinya.

Hasil penelitian tentang jenis tindak verbal terapi dalam intervensi klinis anak autis secara ringkas digambarkan dalam Tabel 1.

\section{Fungsi Tindak Verbal Terapi}

Dalam penelitian ini yang dimaksud fungsi tindak verbal terapis adalah maksud dan tujuan penggunaan tuturan terapis dikaitkan dengan konteks klinis (persiapan terapi, pelaksanaan kegiatan terapi, dan akhir terapi). Hasil penelitian tindak bahasa terapi menunjukkan ada tiga jenis fungsi tindak ilokusi terapis, yaitu fungsi direktif, asertif, dan ekspresif.

Pertama, fungsi direktif merupakan ujaran yang mengharapkan mitra tutur melakukan suatu tindakan. Dengan tin- dak direktif ini terapis menghendaki agar anak autis melakukan tindakan tertentu saat intervensi klinis. Berdasarkan hasil penelitian ditemukan penggunaan tindak direktif yang memiliki fungsi memerintah atau menyuruh, mengajak atau mendorong, melarang atau menolak, meminta, menanyakan, dan menyetujui.

Penggunaan fungsi memerintah atau menyuruh dalam konteks klinis, melalui tuturannya, terapis bermaksud menyuruh anak autis melakukan tindakan tertentu sesuai dengan harapan terapis. Dalam konteks persiapan terapi, saat anak autis tidak ada kontak mata dan tidak fokus, terapis menggunakan tuturan berikut ini.

Konteks Persiapan Terapi

Andi : (tidak fokus dan tidak ada kontak mata)

Terapis: Andi lihat! Lihat! Andi! Andi lihat! Andi : (menatap terapis)

Tuturan terapis berintonasi perintah dengan pola tuturan sederhana (tuturan pendek yang terdiri atas satu atau dua kata) seperti dalam kutipan tersebut memiliki fungsi menyuruh anak autis agar fokus dan ada kontak mata ketika dipanggil terapis. Dengan menggunakan tuturan perintah berulang-ulang terapis bermaksud menyuruh anak autis ketika dipanggil agar menatap terapis dan berkonsentrasi.

Tabel 1. Jenis Tindak Bahasa Terapi untuk Anak Autis

\begin{tabular}{|c|c|c|}
\hline No. & Jenis Ilokusi & Indikator Tuturan \\
\hline \multirow[t]{6}{*}{1} & Tindak Direktif & 1. Bentuk perintah atau suruhan \\
\hline & & 2. Bentuk ajakan atau dorongan \\
\hline & & 3. Bentuk permintaan \\
\hline & & 4. Bentuk penolakan atau larangan \\
\hline & & 5. Bentuk pertanyaan dengan jawaban singkat \\
\hline & & 6. Bentuk persetujuan atas tindakan \\
\hline \multirow[t]{2}{*}{2} & Tindak Asertif & 1. Bentuk pernyataan \\
\hline & & 2. Bentuk penjelasan atau pendeskripsian. \\
\hline \multirow[t]{2}{*}{3} & Tindak Ekspresif & 1. Bentuk pujian atau penghargaan \\
\hline & & 2. Bentuk pengucapan syukur atau terima kasih \\
\hline
\end{tabular}

LITERA, Volume 13, Nomor 2, Oktober 2014 
Fungsi mengajak atau mendorong digunakan oleh terapis untuk mengajak anak autis agar mau melakukan suatu tindakan sebagaimana diharapkan terapis.

PelaksanaanTerapi

Konteks Mengimitasi Suara dan Kata

Andi : (berdiri dan tidak fokus)

Terapis: Ayo menyanyi! Tirukan suara kucing!

Andi : (diam)

Terapis : Ayo tiru!

Dalam intervensi klinis anak autis, tuturan terapis ditandai dengan tuturan "ayo" mempunyai fungsi mengajak dan sekaligus mendorong agar anak autis termotivasi untuk melakukan kegiatan mengimitasi suara dan kata sebagaimana diharapkan terapis. Dengan menggunakan tuturan sederhana terapis mengajak dan mendorong anak autis agar menirukan suara kucing seperti yang dinyanyikan oleh terapis.

Fungsi menolak atau melarang digunakan oleh terapis untuk menolak respon anak autis yang tidak benar. Berikut ini contoh tuturan terapis yang mempunyai fungsi menolak tindakan anak autis.

Konteks Mengidentifikasi/Menyebutkan Bagian-bagian Tubuh

Andi : (rewel sambil berdiri)

Terapis: Tidak! (sambil menggelengkan kepala) (menunjuk dada)

Andi : (menepuk kepala)

Terapis : Tidak! Tidak Andi!

Dalam kegiatan mengidentifikasi atau menyebutkan bagian-bagian tubuh, terapis menggunakan tuturan "tidak" disertai gelengan kepala. Tuturan ini mempunyai fungsi menolak tindakan anak autis yang rewel sambil berdiri ketika pembelajaran mengidentifikasi bagian-bagian tubuh. Dengan menggunakan tuturan "tidak" terapis bermaksud menolak atas respon atau jawaban salah dari anak autis. Hasil penelitian juga menunjukkan bahwa perkataan "tidak" juga untuk menegaskan sesuatu yang tidak boleh dikerjakan oleh anak.

Fungsi meminta digunakan oleh terapis untuk meminta atau mengharapkan respon anak autis. Berikut ini contoh tuturan terapis yang mempunyai fungsi meminta atau mengharapkan.

Konteks Mengimitasi Gerakan Motorik

Andi : (bermain gunting)

Terapis : Minta Andi! Sini minta!

Andi : (diam)

Dalam konteks mengimitasi gerakan motorik halus, terapis menggunakan tuturan Minta Andi! Sini minta! Tuturan tersebut berfungsi untuk meminta atau mengharapkan sesuatu kepada anak autis. Terapis meminta agar anak autis memberikan gunting kepada terapis dan berharap agar tidak bermain gunting. Bermain gunting dapat membahayakan diri anak autis.

Fungsi menanyakan digunakan oleh terapis untuk menanyakan sesuatu kepada anak autis dengan harapan mendapatkan informasi tentang sesuatu. Berikut ini contoh tuturan terapis yang mempunyai fungsi menanyakan.

Konteks Menjawab Pertanyaan Sosial

Andi : (diam)

Terapis : Siapa namamu? Di mana rumahmu? Berapa kakakmu?

Andi : (menjawab dengan suara pelan)

Dalam kegiatan menjawab pertanyaan sosial, terapis menggunakan tuturan sederhana dalam bentuk pertanyaan dengan jawaban singkat apa, siapa, mana, dimana, berapa, dan jawaban ya/tidak. Tuturan ini berfungsi menanyakan sesuatu untuk memperoleh jawaban atau informasi tentang identitas anak autis. Hasil penelitian ini sesuai dengan pendapat SES (2002:15). Bagi anak autis yang mengalami gangguan komunikasi ada cara penyampaian tuturan pertanyaan yang dilakukan oleh terapis, yaitu dengan memberikan pertanyaan tertutup. Strategi pertanyaan 
tertutup digunakan untuk memudahkan anak autis dalam menjawabnya. Dalam kegiatan intervensi klinis, terapis tidak menggunakan pertanyaan terbuka karena bagi anak autis sulit menjawabnya.

Fungsi menyetujui digunakan oleh terapis untuk menyetujui respon atau tindakan anak autis. Berikut ini contoh tuturan terapis yang mempunyai fungsi menyetujui.

Konteks Mengakhiri Terapi

Andi : (tidak fokus)

Terapis: (memanggil nama Andi!)

Andi : (menatap terapis)

Terapis: Ok. (sambil gestur ibu jari) Ya Andi.

Dalam konteks mengakhiri kegiatan terapi, terapis menggunakan tuturan "Ok". Tuturan tersebut berfungsi untuk menyetujui respon atau tindakan anak autis. Ketika anak autis dapat melakukan perintah dan tindakan dengan benar atau sesuai harapan, biasanya terapis menggunakan tuturan, misalnya Ya, Ok. Ok Andi (sambil menggunakan gestur ibu jari).

Kedua, fungsi asertif. Fungsi tuturan ini mengikat terapis akan kebenaran apa yang diujarkannya. Fungsi asertif digunakan untuk menyatakan sikap dan memberikan penjelasan tentang sesuatu. Hasil penelitian menunjukkan bahwa tindak asertif mempunyai dua fungsi, yaitu menyatakan dan menjelaskan.

Fungsi menyatakan digunakan oleh terapis untuk menyatakan sikapnya terhadap respon atau tindakan anak autis. Berikut ini contoh tuturan terapis yang mempunyai fungsi menyatakan.

Konteks Mengidentifikasi/Menyebutkan Bentuk Benda

Terapis: (menanyakan bentuk benda Ini bentuk?)

Andi : Makan.(tidakfokus dan minta makan) Terapis: Oh, salah. Belum waktunya.

Andi : (rewel)

Dalam intervensi klinis anak autis, khususnya pada kegiatan mengidentifikasi bentuk, terapis menggunakan tuturan "oh salah", dan "belum waktunya" untuk menyatakan sikap bahwa tindakan yang dilakukan oleh anak autis salah. Pada saat pembelajaran mengidentifikasi bentuk benda dan terapis menanyakan tentang bentuk apa, tiba-tiba anak autis menjawab "makan" dan terus merengek minta makan. Terapis menggunakan tuturan "belum waktunya" mempunyai fungsi menyatakan sikap tegasnya bahwa anak autis harus mematuhi kegiatan terapi.

Selanjutnya fungsi menjelaskan digunakan untuk menjelaskan atau mendeskripsikan benda atau tentang sesuatu. Berikut ini contoh tuturan terapis yang mempunyai fungsi menjelaskan.

Konteks Mengidentifikasi/Menyebutkan Benda

Terapis: (menanyakan bentuk benda ini bentuk?)

Andi : (diam)

Terapis: Ini buah. Ini apel. Ini bulat.

Andi : (rewel)

Dalam konteks mengidentifikasi atau menyebutkan benda, terapis menggunakan tuturan Ini buah. Ini apel. Ini bulat. Tuturan tersebut mempunyai fungsi menjelaskan atau mendeskripsikan benda (yang dimaksud adalah buah apel). Hasil penelitian menunjukkan bahwa fungsi ini biasanya digunakan oleh terapis untuk menjelaskan tentang sesuatu yang berhubungan dengan materi pembelajaran.

Ketiga, fungsi ekspresif. Tindak ekspresif merupakan tindak tutur yang menyatakan perasaan atau ungkapan suasana hati terapis. Fungsi ekspresif meliputi fungsi memuji dan mengucapkan terima kasih.

Fungsi memuji digunakan untuk memberikan pujian atau penghargaan atas respon dan tindakan positif anak autis. Berikut ini contoh tuturan terapis yang mempunyai fungsi memuji atau menghargai.

Konteks Mengimitasi suara dan Kata

Terapis: (menyuruh anak autis menirukan suara ayam) 
Andi : (menirukan dengan benar)

Terapis : Andi pintar. Hebat ye...

Dalam kegiatan mengimitasi suara, terapis secara eksplisit menggunakan tuturan "pintar" dan "hebat". Tuturan ini dimaksudkan untuk memuji atau menghargai respon dan tindakan yang benar dari anak autis. Dalam kegiatan intervensi klinis seringkali terapis menggunakan tuturan pujian dengan tujuan menyemangati dan memuji tindakan positif anak autis.

Fungsi berterima kasih digunakan untuk mengucapkan terima kasih atas respon dan tindakan anak autis yang sesuai dengan harapan terapis. Berikut ini contoh tuturan terapis yang mempunyai fungsi bersyukur dan berterima kasih.

Konteks Mengakhiri Terapi

Terapis: (menberitahukan waktunya pulang) Andi : (merapikan meja)

Terapis : Alhamdulillah. Terima kasih Andi.

Pada akhir kegiatan terapi, terapis menggunakan tuturan "alhamdulillah" dan "terima kasih". Tuturan ini berfungsi untuk mengungkapkan suasana hati terapis saat anak autis dapat melakukan suatu tindakan yang positif. Misalnya, ketika mengakhiri kegiatan terapi tiba-tiba anak autis merapikan meja. Mengetahui sikap anak autis ini dengan senang hati terapis mengucapkan syukur dan terima kasih. Dalam intervensi klinis anak autis fungsi ekspresif ini mempunyai muatan edukasi. Memuji merupakan bentuk penguatan ( $r e-$ inforcement) terhadap apa yang dilakukan oleh anak autis. Dalam kegiatan intervensi klinis, terapis tidak memberikan hukuman (punisment) ketika anak autis melakukan kesalahan. Dalam tindak bahasa terapis tidak terdapat tindak kekerasan. Terapis memberikan apresiasi positif terhadap tindakan anak autis yang benar dengan cara memuji, menghargai, atau mengucapkan terima kasih.
Hasil penelitian fungsi tindak verbal terapi dalam intervensi klinis anak autis secara ringkas digambarkan dalam Tabel 2.

\section{Strategi Tindak Verbal Terapi}

Dalam penelitian ini strategi tindak bertutur terapis diidentifikasi berdasarkan kelangsungan cara penuturan terapis dan cara mendapatkan fokus atau perhatian anak autis. Hasil penelitian menunjukkan bahwa dalam intervensi klinis anak autis, terapis menggunakan strategi bertutur langsung (literal) melalui strategi pemanggilan, strategi pemberian petunjuk, dan strategi visual atau model.

Pertama, strategi pemanggilan. Strategi pemanggilan dilakukan dengan cara memanggil langsung nama anak dengan maksud memperoleh perhatian dan respon. Hasil penelitian menunjukkan bahwa dalam tindak tutur langsung-literal, terapis menggunakan strategi pemanggilan seperti berikut ini.

Persiapan Terapi

Andi : (tidak fokus)

Tr : Andi! Halo Andi!

Andi : (diam)

Terapis : Andi, lihat!

Pada kegiatan persiapan terapi, terapis memerintah anak autis dengan menggunakan strategi pemanggilan. Strategi pemanggilan dengan menyebut langsung nama anak autis ini biasanya dilakukan secara berulang-ulang sampai dengan menunggu responnya. Demikian pula, dalam pelaksanaan kegiatan terapi seringkali terapis menggunakan strategi pemanggilan nama anak secara langsung. Ketika anak tidak fokus atau tidak konsentrasi secara spontan terapis memanggil nama anak disertai penggunaan sentuhan fisik, seperti menepuk dagu dan mengelus pipi. Strategi pemanggilan ini dimaksudkan untuk membangun kontak mata dan fokus agar anak dapat melakukan perintah terapis. 
Tabel 2. Fungsi Tindak Bahasa Terapi untuk Anak Autis

\begin{tabular}{|c|c|c|c|}
\hline No. & $\begin{array}{l}\text { Fungsi llokusi } \\
\text { Terapis }\end{array}$ & Indikator & Realisasi Tuturan Terapis \\
\hline \multirow[t]{12}{*}{1} & \multirow[t]{12}{*}{ Fungsi Direktif } & Memerintah atau & Tuturan bermaksud memerintah atau menyuruh. \\
\hline & & menyuruh & \\
\hline & & $\begin{array}{l}\text { Mengajak atau } \\
\text { mendorong }\end{array}$ & $\begin{array}{l}\text { Tuturan mengajak.. Misalnya, Ayo duduk! Ayo } \\
\text { menyanyi! Ayo tiru "o"! }\end{array}$ \\
\hline & & $\begin{array}{l}\text { Meminta atau } \\
\text { mengharapkan }\end{array}$ & $\begin{array}{l}\text { Tuturan berfungsi meminta. Misalnya, } B u \text { Ani } \\
\text { minta! Minta! (meminta gunting agar tidak } \\
\text { bermain gunting) }\end{array}$ \\
\hline & & Menolak atau & Tuturan bermaksud menolak atau melarang. \\
\hline & & melarang & Misalnya:,Andi tidak! Tidak! Tidak rewel! \\
\hline & & & Tuturan "jangan" dan "sst" jarang digunakan. \\
\hline & & Menanyakan & Tuturan menanyakan berfungsi mendapatkan \\
\hline & & & jawaban singkat. Mmisalnya: Apa? Siapa? Mana? \\
\hline & & & Dimana? Berapa?Ya/Tidak! \\
\hline & & Menyetujui & Tuturan berfungsi menyetujui. \\
\hline & & & Misalnya, Ok Andi...Ok. \\
\hline \multirow[t]{5}{*}{2} & \multirow[t]{5}{*}{ Fungsi Asertif } & Menyatakan & Tuturan bermaksud menyatakan sikap \\
\hline & & & Misalnya, Belum waktunya. \\
\hline & & Menjelaskan & Tuturan bermaksud menjelaskan atau \\
\hline & & atau & mendeskripsikan. Misalnya Ini mata. \\
\hline & & mendeskripsikan & Mata ada dua. Mata untuk... \\
\hline \multirow[t]{4}{*}{3} & Fungsi & Memuji atau & Tuturan bermaksud memuji atau menghargai. \\
\hline & \multirow{3}{*}{ Ekspresif } & menghargai & Misalnya, Pintar. Hebat. \\
\hline & & Bersyukur dan & Tuturan bermaksud mengungkapkan \\
\hline & & Berterima kasih & $\begin{array}{l}\text { rasa syukur dan rasa terima kasih. Misalnya: } \\
\text { Misalnya, Alhamdulillah. Terima kasih Andi. }\end{array}$ \\
\hline
\end{tabular}

Kedua, strategi pemberian petunjuk. Dalam intervensi klinis, terapis menggunakan strategi pemberian petunjuk dan perintah secara langsung. Strategi pemberian petunjuk ini seperti dalam tuturan berikut ini.

Kegiatan Melakukan Perintah Sederhana

Andi : (berdiri dan tidak fokus)

Tr : Duduk! Duduk!

Andi : (diam)

Terapis : Andi, lihat!

Hasil penelitian ini sesuai dengan pendapat SES (2002:15). Strategi pemberian petunjuk dilakukan untuk membantu memudahkan memahami maksud tuturan. Petunjuk yang diberikan secara langsung, jelas, dan singkat. Langsung artinya petunjuk yang diberikan dalam bentuk tuturan literal dan lugas. Jelas artinya instruksi atau perintah yang diberikan mudah dipahami dan dimengerti. Singkat artinya hanya menggunakan satu perintah sederhana. Anak autis tidak memahamai bentuk perintah lebih dari satu sekaligus dan tidak menggunakan kalimat panjang. Penggunaan kalimat yang panjang akan membingungkan anak autis.

Ketiga, strategi visual atau model. Dalam kegiatan intervensi klinis seringkali terapis menggunakan strategi tuturan langsung disertai contoh atau model. Dengan strategi ini anak autis dapat dengan mudah memahami perintah terapis. Berikut ini contoh penggunaan strategi visual. 
Tabel 3. Strategi Tindak Verbal Terapi Untuk Anak Autis

\begin{tabular}{lll}
\hline No. & $\begin{array}{l}\text { Strategi Tindak } \\
\text { Bertutur Langsung (Literal) }\end{array}$ & Indikator \\
\hline 1 & Strategi Pemanggilan & Pemanggilan langsung nama anak \\
2 & Strategi Pemberian Petunjuk & Pemberian petunjuk langsung, jelas, dan singkat \\
3 & Strategi Visual atau Model & $\begin{array}{l}\text { Pemberian contoh langsung melalui peragaan, } \\
\text { gambar, gerakan, dan nyanyian }\end{array}$ \\
\hline
\end{tabular}

Konteks Mengimitasi Gerakan Motorik Halus (Menulis)

Terapis: Buat lingkaran! Lingkaran kecil! Lingkaran kecil! Lingkaran besar! (memberikan contoh dengan peragaan)

Andi : (menggambar lingkaran)

Dalam kegiatan imitasi tindakan terhadap benda, terapis mengajak anak autis melakukan tindakan dengan menggunakan strategi contoh atau peragaan. Melalui visualisasi, anak autis dapat dengan mudah memahami perintah dan maksud tuturan terapis. Hasil penelitian ini sesuai dengan pendapat SES (2002:5). Bagi anak autis yang mengalami gangguan komunikasi dapat dibantu dengan strategi penggunaan visual atau model. Strategi penggunaan visual atau model memudahkan anak dalam memahami maksud terapis dan komunikasi klinis menjadi efektif.

Hasil penelitian tentang strategi tindak verbal terapi untuk anak autis secara ringkas digambarkan dalam Tabel 3.

\section{SIMPULAN}

Dengan menggunakan taksonomi tindak tutur, hasil penelitian menunjukkan bahwa dalam intervensi klinis anak autis gangguan komunikasi, terapis menggunakan tindak bertutur ilokusi. Terapis tidak menggunakan tindak lokusi dan perlokusi.

Tindak ilokusi terapis diidentifikasi berdasarkan jenis, fungsi, dan strategi den- gan ancangan pragmatik klinis. Berdasarkan hasil penelitian, tindak ilokusi terapis ditemukan tiga jenis tuturan terapis, yaitu: (1) direktif, (2) asertif, dan (3) ekspresif. Sesuai dengan rumusan masalah penelitian, dalam penelitian ini tidak ditemukan jenis tindak tutur deklaratif dan komisif. Terapis tidak menggunakan kedua jenis tindak tutur ini karena anak autis tidak memahami tuturan yang mengandung janji, pengharapan, idiom, dan bahasa klise.

Jenis tindak direktif terapis ditandai penggunaan bentuk tuturan, yaitu: (1) perintah dengan menggunakan intonasi perintah, (2) bentuk ajakan, (3) permintaan atau pengharapan, (4) penolakan atau larangan, (5) pertanyaan dengan jawaban singkat, dan (6) bentuk persetujuan. Dalam tindak asertif ditemukan dua bentuk tuturan, yaitu: (1) bentuk pernyataan dan (2) penjelasan. Dalam intervensi klinis anak autis, terapis menggunakan dua jenis tindak ekspresif, yaitu (1) bentuk pujian atau penghargaan dan (2) bersyukur atau berterima kasih.

Dalam penelitian ini tidak semua indikator tindak ilokusi digunakan oleh terapis saat intervensi klinis anak autis. Hal ini disebabkan oleh adanya keterbatasan kondisi mitra tutur. Anak autis sebagai mitra tutur memiliki hambatan komunikasi dan interaksi sosial berimplikasi pada tuturan terapis. Dalam percakapan klinis, terapis dalam tuturannya memilih jenis tindak tutur ilokusi dengan pola sederhana sesuai dengan 
kemampuan dan hambatan mitra tutur (anak autis).

Berdasarkan hasil penelitian, fungsi ilokusi terapi untuk anak autis diklasifikasikan berdasarkan tiga jenis, yaitu (1) fungsi direktif, (2) asertif, dan (3) ekspresif. Hasil penelitian tentang fungsi tindak verbal terapis menunjukkan bahwa dalam tindak ilokusi terapis tidak ditemukan fungsi deklaratif dan komisif.

Dalam intervensi klinis anak autis, tindak direktif terapis mempunyai fungsi memerintah, mengajak, meminta, melarang, menanyakan, dan menyetujui. Tidak semua fungsi tindak ilokusi muncul saat intervensi klinis anak autis. Fungsi tindak ilokusi digunakan oleh terapis sesuai dengan maksud komunikasi klinis. Tindak memerintah bermaksud menyuruh anak autis untuk melakukan tindakan. Tindak mengajak untuk mendorong anak autis agar melakukan sesuatu sesuai dengan perintah terapis. Tindak melarang bermaksud menolak tindakan yang tidak diharapkan oleh terapis. Dalam tindak ini terapis menolak tindakan anak autis yang menyimpang dan tidak sesuai dengan harapan terapis. Tindak meminta bermaksud mengharapkan agar anak autis melakukan tindakan tertentu berdasarkan instruksi terapis. Tindak menanyakan dimaksudkan memperoleh jawaban atau informasi tentang sesuatu dari anak autis. Tindak menyetujui ini digunakan untuk membenarkan tindakan anak autis.

Tindak asertif terapis berfungsi menyatakan dan menjelaskan atau mendeskripsikan tentang sesuatu. Tindak menyatakan berhubungan dengan pernyataan sikap terapis atas tindakan anak autis. Tindak memuji berhubungan dengan penghargaan terhadap tindakan positif anak autis, sedangkan tindak berterima kasih dimaksudkan untuk mengungkapkan rasa syukur dan terima kasih atas tindakan anak autis yang sesuai dengan perintah terapis.
Tindak ekspresif memiliki fungsi mengekspresikan suasana hati terapis. Tindak ini mempunyai maksud mengungkapkan rasa syukur dan terima kasih atas tindakan positif anak autis.

Berdasarkan hasil penelitian, strategi tindak verbal terapi untuk anak autis diklasifikasikan berdasarkan cara kelangsungan penuturan terapis dan cara membangun fokus atau kontak mata anak autis. Dalam intervensi klinis, terapis menggunakan tuturan langsung yang bermakna sesuai kata yang diujarkannya.

Untuk membangun fokus dan pemahaman maksud komunikasi klinis, terapis menggunakan tiga strategi, yaitu: (1) pemanggilan, (2) pemberian petunjuk, dan (3) visual atau model. Dalam intervensi klinis anak autis, strategi pemanggilan dilakukan dengan cara memanggil langsung nama anak autis. Pemanggilan nama anak dilakukan berulang-ulang hingga mendapatkan fokus dan respon yang benar. Ketidakmampuan merespon merupakan salah satu ciri spektrum komunikasi, ditandai adanya ketidakmampuan memulai percakapan atau melanjutkan percakapan dengan terapis meskipun percakapan sederhana.

Strategi pemberian petunjuk atau instruksi. Dalam strategi pemberian petunjuk ini terapis menggunakan tuturan langsung (harfiah) dalam memberikan perintah dan penjelasan pada anak autis. Strategi tuturan tidak langsung (nonharfiah), seperti bahasa kias tidak digunakan oleh terapis saat intervensi klinis. Pemberian petunjuk dilakukan secara langsung, jelas dan singkat dengan menggunakan satu perintah.

Strategi penggunaan visual atau model. Untuk memudahkan anak autis dalam memahami maksud komunikasi klinis, terapis menggunakan bantuan gambar, contoh, model, atau tiruan tindakan. Gambar atau contoh yang digunakan dalam bentuk konkret. Tiruan tindakan 
dapat berbentuk imitasi suara, kata, dan tindakan atau gerakan.

Selanjutnya, berdasarkan hasil penelitian tindak bahasa terapi untuk anak autis terdapat beberapa saran diberikan untuk pihak terkait penanganan anak autis.

Disarankan untuk para terapis, ahli klinis, dan guru autis ada pemahaman terhadap tindak bahasa terapi untuk anak autis gangguan komunikasi. Pemahaman terhadap tindak bahasa terapi perlu dilakukan dengan memilih jenis, fungsi, dan strategi tindak bahasa yang sesuai dengan karakteristik individual anak. Tidak semua bentuk tindak bahasa dapat digunakan dalam intervensi klinis anak autis. Oleh karena itu, hasil penelitian ini disarankan dapat dimanfaatkan sebagai bahan pertimbangan untuk komunikasi klinis anak autis atau anak yang mengalami hambatan komunikasi disertai gangguan kompleks.

Hasil penelitian ini dapat dijadikan bahan pertimbangan untuk perancangan kurikulum, khususnya kurikulum anak berkebutuhan khusus penderita autis. Hasil deskripsi dan eksplanasi tindak bahasa terapi dapat dijadikan pertimbangan dalam penyusunan kurikulum autis, khususnya dalam pengembangan materi dan pemilihan strategi komunikasi atau pembelajaran anak autis pada program terapi tingkat awal dan menengah.

Hasil penelitian ini dapat digunakan sebagai masukan bagi guru sekolah inklusi yang siswanya memiliki riwayat autis. Hasil deskripsi dan eksplanasi tindak bahasa terapi dapat dijadikan pertimbangan dan rujukan oleh guru dalam interaksi pembelajaran di kelas reguler yang melaksanakan kegiatan pembelajaran inklusi dengan anak autis. Pemahaman dan pemilihan bentuk, fungsi, dan strategi tindak bahasa yang tepat oleh guru sekolah inklusi dapat membantu anak autis dalam memahami materi pembelajaran.

\section{UCAPAN TERIMA KASIH}

Artikel ini didasarkan atas hasil penelitian yang berjudul Tindak Bahasa Terapis dalam Internesi Klinis Anak Autis yang didanai oleh DP2M DIKTI melalui skim Hibah Disertasi Doktor. Laporan akhir penelitian dalam bentuk artikel ini dapat diselesaikan berkat bantuan beberapa pihak. Pertama, Dosen Pembimbing Disertasi dan Direktur Pascasarjana Universitas Negeri Malang yang telah memberikan rekomendasi usulan Hibah Disertasi Doktor. Kedua, Ketua LPM UNISMA yang telah menyetujui usulan dan memberikan pembinaan terhadap peneliti. Ketiga, Direktur DP2M DIKTI yang telah menyetujui dan mendanai penelitian hibah disertasi doktor. Keempat, segenap Pengurus Unit Instalasi Autis RSI UNISMA Malang yang telah banyak membantu dalam pengumpulan data penelitian.

\section{DAFTAR PUSTAKA}

Cummings, Louise.1999. Pragmatics, A Multidiciplinary Perspective. Oxford University Press Inc., New York.

Cummings, Louise. 2010. Pragmatik Klinis. Kajian tentang Penggunaan dan Gangguan Bahasa Secara Klinis. Terjemahan (Editor) Prof. Dr. Abdul Syukur Ibrahim. Yogjakarta: Pustaka Pelajar.

Delphie, Bandi. 2009. Pendidikan Anak Autis. Klaten: PT Intan Sejati.

Instalasi Mutiara Hati, 2006. Penatalaksanaan Holistik Anak Autisma dan Anak Dengan Kebutuhan Khusus. Malang: Rumah Sakit Islam Malang UNISMA.

Nugroho. 2011. Mensos Dukung Pembuatan Film Dokumenter Autisme. http: //www. rri.co.id/index.php. Diunduh, 27 April 2011.

Owens, Robert E. 1991. Language Disorder. A Functional Approach to Assesment dan Intervention. New York: Macmillan Publishing Company.

Priyatna, Andri. 2010. Amazing Autizm, Memahami, Mengasuh, dan Mendidik Anak Autis. Jakarta: PT Gramedia. 
Searle, J.R. 1969. Speech Acts: An Essay in The Philosophy of Language. Cambridge: Cambridge University Press.

Specialist Education Service (SES). Minister of Education New Zealand. 2002. Autistic Spectrum Disorders (ASD): A
Resource for Teachers. ABILL Publishing. New Zealand.

Wijayakusuma, Hembing. 2008. Psikoterapi Anak Autisma. Teknik Bermain Kreatif Nonverbal dan Verbal. Terapi Khusus Untuk Autisma. Jakarta: Pustaka Populer Obor. 